\title{
Fibromyalgia: How is His Impact on Family Life?
}

\author{
Rodríguez Pérez M* \\ Faculty of Biochemistry and Envieronmental Sciences, Spain
}

*Corresponding author: Rodríguez-Pérez M, Faculty of Biochemistry and Envieronmental Sciences, Biochemistry Section, University of Castilla-La Mancha, Avda. Carlos III S/N. 45071, Toledo, Spain

\begin{tabular}{|c|c|}
\hline ARTICLE INFO & ABSTRACT \\
\hline Received: November 17, 2019 & Fibromyalgia, like other health problems that occur with chronic pain, can produce \\
\hline Published: January 06, 2020 & $\begin{array}{l}\text { different consequences in the life of the person who suffers from it, as well as in its } \\
\text { closest environment. In this mini review, a general approach is made to focus on the }\end{array}$ \\
\hline $\begin{array}{l}\text { Citation: Rodríguez Pérez M. Fibromyalgia: } \\
\text { How is His Impact on Family Life?. Biomed }\end{array}$ & $\begin{array}{l}\text { consequences described are not an inevitable fact or necessarily linked to the illness. } \\
\text { Heterogeneity is a proven fact among people who share this diagnosis and therfore, the } \\
\text { consequences too. }\end{array}$ \\
\hline
\end{tabular}

J Sci \& Tech Res 24(2)-2020. BJSTR. MS.ID.004023.

\section{Mini Review}

Fibromyalgia (FM) is a chronic patology of pain state accompanied by various nonspecific symptoms, being considered as a mixture of psychological, physical and social disorders which mainly affects women [1-3]. In 1990, the American College of Rheumatology established that two conditions are needed to identificate FM: diffuse musculoskeletal pain, for at least 3 months and, at least, pain in 11 of 18 predetermined body sites called tender points [1]. Many revision of the criteria have been made since then, the last one in 2016. These most recent criteria confirm that other clinical variables should be considered [4]. Furthermore, FM presents a large degree of comorbid conditions like anxiety, depression, sleep disorders and painful, with diverse origins, like headache [5]. Due to that, many treatments have been tested to relieve the pain and recently, it has been shown that both yoga and mindfulness can improve the quality of sleep and decrease pain of FM patients [6,7]. However, the origin of the FM is not completely clear and for that reason, there is many investigations based on it.

\section{Family Impact}

An study of Collado et al. in 2014 made in Spain [8] affirms that the patients with FM present a $23 \%$ of mild/moderate family dysfuntion and $8 \%$ severe family dysfunction. Furthermore, $23 \%$ of patients were scarcely safisfied or not satisfied at all with their familia life, meanwhile 59\% reported difficulties in their relationship with their partner. There was a $17 \%$ of patients who divorced and, a half of them, thought that the FM had influenced on it. It should not be forgotten that if there are children, they need to be aware of the fact that their mothers are no more completely self-sufficient, with the great impact caused on them and of course in the patient, who mostly will be the mother [9]. Collado, et al. [8] also confirm that $45 \%$ of the FM patients of that study said that their family did not understand the disease and they did not follow the doctors' recommendations.

Moreover, it is important to consider role changes when a woman is diagnosed with FM, since a redistribution of tasks must occur with the difficulties that it can cause to family balance. At the beginning of the disease, women try to continue with all the housework, but they quickly realize that the must stop, leading to this fact the loss of the role they traditionally have [9]. It is also described that the disease is often associated with an employment status change and loos of ability to work, due to the fact that in many cases, the patients do not inform their work environment about their disease for fear of losing the job [8]. Another point to consider are the problems related to marital relationships, since on the one hand, patients' partners make plans outside home with other people which can not include them and on the other hand, different difficulties appear in sexual relations due to, among other facts, sexual stiffness and body image disorders $[9,10]$. 


\section{Conclusion}

As a conclusion, it could be said that the real impact of FM on family life of the patients is very complicated and complex to establish. One of the principal causes may be the fact that many people are undiagnosed and until they are correctly diagnosed, not only suffer episodes of pain but also misunderstanding. It is crucial to continue researching in this syndrome in order to improve both the diagnosis and the quality of life of the FM patients.

\section{Acknowledgement}

None.

\section{Conflict of Interest}

No conflict of interest.

\section{References}

1. Affaitati G, Costantini R, Tana C, Cipollone F, Giamberardino MA (2019) Co-occurrence of pain syndromes. J Neural Transm 1-22.

2. Dias RCA, Kulak Junior J, Ferreira da Costa EH, Nisihara RM (2019) Fibromyalgia, sleep disturbance and menopause: Is there a relationship? A literature reviews. Int J of Rheum Dis 22(11): 1961-1971.

3. Matarán Peñarrocha GA, Castro Sánchez AM, Carballo Garcñua G, Moreno Lorenzo C, Carreño TP, et al. (2009) Influence of Craniosacral Therapy of

ISSN: 2574-1241

DOI: 10.26717/BJSTR.2020.24.004023

Rodríguez Pérez M. Biomed J Sci \& Tech Res

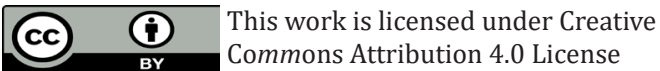

Submission Link: https://biomedres.us/submit-manuscript.php
Anxiety, Depression and Quality of Life in Patients with Fibromyalgia. Evid Based Complement Alternat Med 178769.

4. Wolfe F, Clauw DJ, Fitzcharles MA, Goldenberg DL, Häser W, et al. (2016) Revisions to the 2010/2011 fibromyalgia diagnostic criteria. Semin Arthritis Rheum 46(3): 319-329.

5. Lichtenstein A, Tiosano S, Amital H (2018) The complexities of fibromialgia and its comorbidities. Curr Opin Rheumatol 30(1): 94-100.

6. Park M, Zhnag Y, Price LL, Bannuru RR, Wang Ch (2019) Mindfulness is associated with sleep quality among patients with fibromyalgia. Int J Rheum Dis p. 1-8.

7. Lazaridou A, Koulouris A, Devine JK, Haack M, Jamison RN, et al. (2019) Impact of daily yoga-based exercise on pain, catastrophizing, and sleep amongst individuals with fibromyalgia. J Pain Res 12: 2915-2923.

8. Collado A, Gomez E, Coscolla R, Sunyol R, Solé E, et al. (2014) Work, family and social environment in patients with Fibromyalgia in Spain: an epidemiological study: DPIFFAC study. BMC Health Services Res 14: 513-522.

9. Briones Vozmediano E, Vives Cases C, Goicolea I (2016) I'm not the woman I was: Women's perceptions of the effects of fibormyalgia on private life. Health Care for Women Int 37: 836-854.

10. Matarín Jiménez TM, Fernández Sola C, Hernández Padilla JS, Correa Casado M, Antequera Raynal LH, et al. (2017) Perceptions about the sexuality of women with fibrmyalgia syndrome: a pehenomenlogical study. JAN 73(7): 1646-1656.

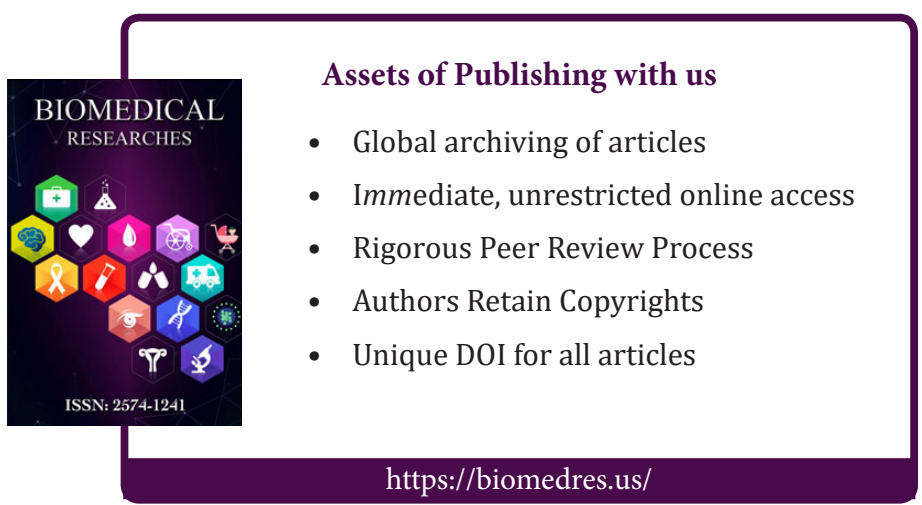

